\title{
Hypocalcemia of The Newborn Due to Red Blood Cell Transfusion: Case Report
}

\author{
Biljana S. Otašević, Bojana O. Petrović, Emina S. Čolak, \\ Tatjana V. Nikolić, Aleksandar O. Stefanović, Ljubinka I. Nikolić \\ University Clinical Center of Serbia, Belgrade, Serbia
}

\section{SUMMARY}

Introduction: Hypocalcemia in preterm infants could occurs as early or late. Causes of late onset of hypocalcaemia: maternal vitamin $D$ deficiency, metabolic syndromes, congenital abnormalities, iatrogenic (transfusion, bicarbonate therapy, phototherapy, antibiotics). Case report: The authors describe the occurrence of late hypocalcemia following transfusion of erythrocytes to the second newborn from a twin pregnancy born prematurely in the $32 / 33$ week of gestation. Mother is diabetic and has hypertension, edema, hypothyroidism, and preeclampsia during pregnancy. Due to the detected pyelectasis in newborn, prophylactic use of cephalexin was introduced. At the end of the first month of life, anemia appear indicating a transfusion. The infant received $50 \mathrm{ml}$ an $0+$ leukodepleted RBC transfusion. Immediately after transfusion was completed, there is a short-term deterioration of the general condition. Cyanosis, stiffness, trismus, and bradycardia appear within a few seconds. DAT was negative, bilirubin in the reference range. After transfusion, laboratory, echosonographic examination, neurological examination, EEG and ECG showed normal results. It was concluded that the adverse reaction was probably caused by transfusion. Conclusion: In preterm infants, hypocalcaemia may occur during transfusion due to citrate overload. Children of diabetic mothers, on antibiotic and photo therapy are at higher risk of developing hypocalcemia. Future studies should evaluate incidence rate of adverse transfusion reactions in newborns.

Keywords: Hypocalcemia, Newborn, Citrate, Transfusion Adverse Reaction

\section{INTRODUCTION}

\section{Neonatal hypocalcemia with a special reference to prematurity}

Hypocalcemia is a common metabolic problem in newborns $[1,2]$. In term and preterm infants weighing $>1500 \mathrm{~g}$ hypocalcemia is defined as total serum calcium concentration $<$ $2 \mathrm{mmol} / \mathrm{L}(8 \mathrm{mg} / \mathrm{dL})$ or ionized calcium $<1.1$ $\mathrm{mmol} / \mathrm{L}(4.4 \mathrm{mg} / \mathrm{L})$. Hypocalcemia in preterm very low birth weight infants weighing $<1500 \mathrm{~g}$ is total serum level $<7 \mathrm{mg} / \mathrm{dl}(1.75 \mathrm{mmol} / \mathrm{L})$ or ionized calcium $<4 \mathrm{mg} / \mathrm{dL}(1 \mathrm{mmol} / \mathrm{L})$. It is also defined as an ionized calcium level $<3.0$ to $4.0 \mathrm{mg} / \mathrm{dL}$ ( $<0.75$ to $1.10 \mathrm{mmol} / \mathrm{L}$ ), depending on the method used $[3,4,5]$. The concentration of serum calcium in newborns reaches levels seen in older children and adults by two weeks of age $[6,7]$.

Early neonatal hypocalcemia occurs within 48-72 hours of birth and it is most com- 
monly seen in preterm infants and very low birth weight infants, infants asphyxiated or depressed at birth, infants of diabetic mother, and intrauterine growth restricted infants. The degree of hypocalcaemia is connected with the severity of diabetes in the mother. Magnesium depletion in mothers with diabetes mellitus causes a hypomagnesaemia state in the fetus, which induces functional hyperparathyroidism and hypocalcaemia in the infant. In addition infants of diabetic mothers have higher serum calcium in utero and this may also suppress the parathyroid gland. A high incidence of birth complications due to difficult delivery and, in some cases, higher incidence of preterm birth in infants of diabetic mother are contributing factors for hypocalcemia. Infants with intrauterine growth restriction may develop hypocalcaemia because of decreased transplacental passage of calcium. In addition, decreased accretion is present if they are delivered preterm or have experienced perinatal asphyxia as a result of placental insufficiency $[8,9]$. Causes of early onset hypocalcaemia: prematurity, preeclampsia, infant of diabetic mother maternal intake of anticonvulsants (phenobarbitone, phenitoin sodium), maternal hyperparathyroidism $[9,10]$. Perinatal stress/asphyxia, neonatal asphyxia, can lead to elevated levels of serum calcitonin, which inhibits calcium leaching from bones and consequential low calcium levels in blood iatrogenic (alkalosis, use of blood products, diuretics, phototherapy, lipid infusions etc) hypoalbuminemia [11].

Causes of late onset of hypocalcaemia: hypomagnesemia, maternal vitamin $\mathrm{D}$ deficiency $[12,13]$, malabsorption, renal insufficiency, hepatobiliary diseas, PTH resistence, primary and secondary hypoparathyroidism, metabolic syndromes (Kenny-caffey syndrome long-chain fatty acyl CoA dehydrogenase deficiency, Kearns-sayre syndrome), congenital abnormalities (DiGeorge syndrome), hypoalbuminemia, iatrogenic (lipid infusions, bicarbonate therapy, loop diuretics, glucocorticosteroids, phosphate therapy, alkalosis, phototherapy, antibiotics $[14,15]$. The cause of late-onset hypocalcemia is usually ingestion of cow's milk or baby formula soymilk with a high phosphate load; elevated serum phosphate leads to hypocalcemia $[3,16]$. Hypocalcemia also appears due to transfusion with citrated blood products $[17,18,19]$.

Signs of neonatal hypocalcemia in- clude hypotonia, tachycardia, tachypnea, apnea, poor feeding, jitteriness, tetany, and seizures. Similar symptoms may occur with hypoglycemia and opioid withdrawal. Neonatal hypocalcemia is diagnosed by measurement of total or ionized serum calcium; ionized calcium is the more physiologic measurement, because it does not require correction for protein concentration and $\mathrm{pH}$. Prolongation of the corrected QT interval (QTc) on ECG also suggests hypocalcemia [5].

\section{Adverse transfusion reactions (ATRs)}

Transfusion-associated adverse reactions (TAARs) can be immune and non-immune, hemolytic and non-hemolytic, and by the time of onset they can be early (24-72 hours after transfusion) and late (after 3 days to 3 months). The most severe are Acute Haemolytic Reactions in response to erythrocyte antigens. Plasma ingredients most often cause allergic reaction, TACO, TRALI. The presence of leukocytes in the blood components gives the largest spectrum of possible side effects: fever, tachycardia tachypnea, nausea, headache, bradycardia, hypotension, GVHD [20].

Hypocalcemia belongs to early noninfectious, non-hemolytic adverse reaction [19].

The prevalence of TAARs was significantly reduced in the transfusions when leukoreduction is done in blood units. Particularly, the prevalence of allergy reactions and febrile non-hemolytic reaction (FNHTRs) were significantly reduced. With the advance in transfusion medicine, blood transfusions are considered to be safe in general. However, there is still some risk of complications. The risks include circulatory overload, transfusion reactions, blood-borne infection, red blood cell allosensitization and hypocalcemia $[21,22]$.

Critically ill patients receiving transfusions are often unstable and can therefore present signs and/or symptoms compatible with adverse transfusion reactions (ATRs) during or after transfusion. Thus ATRs may be underdiagnosed in these critically ill children, with signs and symptoms being attributed to the patient's underlying disease. The incidence of Transfusion adverse events (TAE) is often underestimated, and due to their dependence on passive reporting they are underreported $[23,24,25]$.

The aim: to present case report of a 
newborn with a symptoms of hypocalcemia as transfusion adverse event

\section{CASE REPORT}

The authors describe the occurrence of hypocalcemia following transfusion of erythrocytes (RBC) to the second newborn from a twin pregnancy born prematurely in the $32 / 33$ week of gestation. Due to vital indications for the mother, lung maturation was induced with dexamethasone vial $4 \mathrm{mg} / \mathrm{ml}$, and a cesarean section was performed at $32 / 33$ weeks of gestation. The newborn is male, body weight (BW) $1430 \mathrm{~g}$, body length $41 \mathrm{~cm}$, head circumference $29 \mathrm{~cm}$, Apgar score 8 in the first minute. Pregnancy was induced by assisted reproduction methods (IVF / ET \& It BR \& gt). This is the first pregnancy of this 49-year-old mother, who is diabetic and has hypertension (160/ $90 \mathrm{mmHg}$ ), edema, hypothyroidism, and preeclampsia during pregnancy. Maternal blood group is A RhD positive, anti-erythrocyte antibody screening negative, direct anti-human globulin test (DAT) negative, indirect antihuman globulin test (IAT) negative.

The mother gave written informed consent to publish her and the child's clinical case anonymously.

At birth, in the operating room, the newborn cried. Physical finding: acrocyanotic, normal heart function, but the respirations of the newborn were irregular, so positive pres- sure ventilation (PPV) was applied. Upon admission to the intensive care unit, pediatric status was performed, the child was moderately dyspnoeic, pale pink skin, heart rhythm was correct, tones were clear, noise was not heard, symmetrically audible breathing sound was easily weakened basally. Neurological findings: appropriate for age and gestational age. Non-invasive nasal continuous positive airway pressure (nCPAP) was applied for one day and i.v. hydration was started according to the recommendations [26]. Diffuse oxygen therapy was continued for the next 6 days. Complete blood count of the first day of life in the reference range (Hemoglobin is $205 \mathrm{~g} / \mathrm{L}$, hematocrit 0.597$)$. The blood group of the newborn is $\mathrm{O} \mathrm{RhD}$ positive, direct antihuman globulin test (DAT) negative. Bilirubin was 162.4 $\mu \mathrm{mol} / \mathrm{L}$ on the second day (reference values $102.9-128.6 \mu \mathrm{mol} / \mathrm{L}$ ) so discontinuous phototherapy was applied until bilirubin dropped to normal level within one week.

Minimal enteral intake (MEN) was started (APTAMIL PREMATURE a 400gr given 0.030 ) on the second day, gradually increased in volume and well tolerated with progress in body weight. From the ninth day on full enteral intake. At the end of the first month of life, the newborn reached a weight of $2 \mathrm{~kg}$.

At the end of the second week, there is an increase in laboratory parameters for infection (CRP $15.9 \mathrm{mg} / \mathrm{l}$ ), with good clini-
Figure 1. Display of hemoglobin values by days from birht

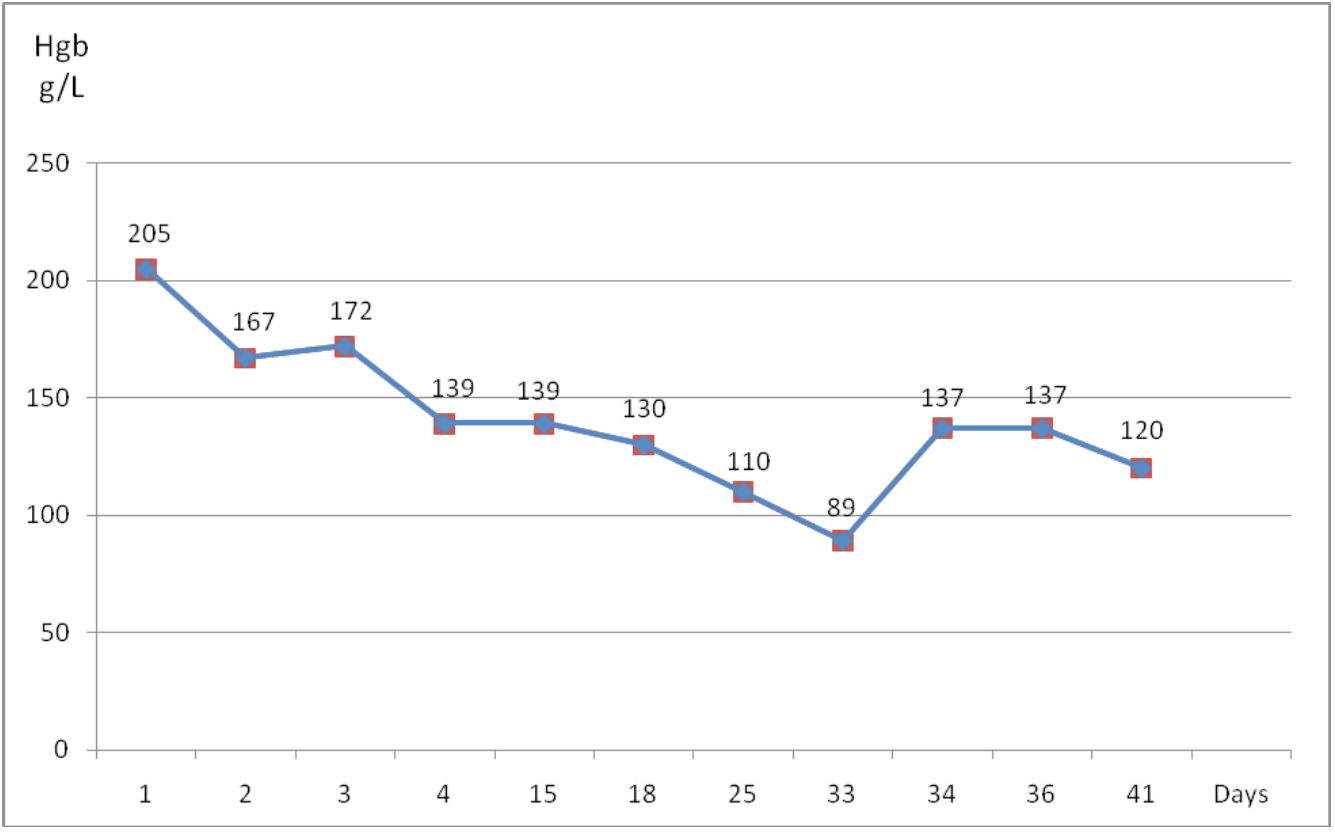


cal condition. As CRP was maintained, urine culture was performed and Klebsiella and Enterobacter were isolated, and ultrasound examination of the abdomen showed pyelectasis of the left kidney (sonographically identified pyelectasia of the left kidney), antibiotic therapy was included according to the antibiogram (Amikacin 26mg at 36h IV, Pamecil amp $75 \mathrm{mg} 12 \mathrm{~h}$ i.v.). Antibiotic and diffuse oxygen therapy continued for the next 10 days. Due to the detected pyelectasis, prophylactic use of cephalexin was introduced.

At the end of the first month of life, signs of anemia appear: hemoglobin $(89 \mathrm{~g} / \mathrm{l}$, Hct 0.25) (Figure 1). After the clinical examination, the pediatrician and the clinical transfusiologist indicate an erythrocyte transfusion. Fifty (50) $\mathrm{ml}$ of $\mathrm{O} \mathrm{RhD}+$ leukodepleted $\mathrm{RBC}$ in optimal additive solution are required. An crossmatch was performed between neonatal EDTA plasma and 2-day-old donor erythrocytes. The reaction was negative. The infant received an $\mathrm{O}+$ leukodepleted RBC transfusion in optimal additive solution. Transfusion rate is in accordance with current recommendations $(5 \mathrm{~mL} / \mathrm{kg} / \mathrm{hr}) /$.

Immediately after the end of the transfusion, there is a short-term deterioration of the general condition. Cyanosis, stiffness, trismus, bradycardia and generalized hypertonia occur within a few seconds. The signs receded after the application of oxygen for a few seconds.

The blood bank was immediately informed and the investigation was initiated. The study of the transfusion reaction did not prove an immune reaction to the applied blood (DAT was negative). He showed no signs of jaundice, bilirubin in the reference range for that age of the child $(14.3 \mu \mathrm{mol} / \mathrm{L})$. After transfusion, laboratory, echosonographic examination of the heart and abdomen, neurological examination, EEG and ECG were performed, which showed normal results. In the further clinical course of the newborn with a stable general condition, care in the crib was continued, with normal vital parameters, with progression to BW. Calcium values 24 hours after transfusion were $2.53 \mathrm{mmol} / \mathrm{L}$ (satisfactory values for preterm LBW infants is greater than 1.75 $\mathrm{mmol} / \mathrm{L}$ ), which is a sign of recovery. It was concluded that the adverse reaction was probably caused by transfusion, in accordance with the existing literature [19].

The newborn is discharged after 44 days of hospitalization (October 30, 2020). At discharge, the body weight is $2650 \mathrm{~g}$, head circumference of newborn is $35 \mathrm{~cm}$, chest circumference is $33 \mathrm{~cm}$, body length is $49 \mathrm{~cm}$ meaning good general condition. Laboratory parameters (CBC, CRP, glycemia, urea, creatinine, proteins, albumins, electrolytes) within the reference values. Screening for preterm ostopenia neat, Ca $2.53 \mathrm{mmol} / \mathrm{l}$, P $2.31 \mathrm{mmol}$ / 1, Alkaline Phosphatase 250 U / L. Skin pink, clean. Head of correct configuration, large fontanelle (LF) at the level of the surrounding bones. The auscultatory finding on the lungs is normal. Cardiac action is rhythmic, tones clear, discreet systolic murmur. Abdomen soft, liver and spleen within physiological limits. The navel finding is neat. Neurological finding: discrete hypotonia of neck and trunk muscles, reflexes are symmetrically induced.

\section{DISCUSSION}

An adverse transfusion reaction occurs in $1.6 \%$ of children in pediatric intensive care units (ICUs) and affects $10.8 \%$ of transfused children in ICUs. In 15 percent of cases, these ATRs represented a vital threat to already critically ill patients [23].

Hypocalcemia is a common metabolic problem in newborns. Hypocalcemia occurs in approximately $30 \%$ neonatus [1]. About $33 \%$ of premature babies develop hypocalcemia within 48 hours of birth (early hypocalcemia), in $10-20 \%$ of babies born to diabetic mothers or other endocrinology disorder, mothers with hyperparathyroidism during pregnancy, maternal hypovitaminosis $\mathrm{D}$ during pregnancy [10]. Hypocalcaemia can occur even in the absence of risk factors [1].

During pregnancy, calcium $(\mathrm{Ca})$ is transferred actively from the maternal circulation to the fetus by a transplacental Ca pump. The majority of fetal Ca accretion occurs in the third trimester. This process results in higher plasma Ca concentrations in the fetus than in the mother, which in turn results in fetal total and ionized Ca concentrations of 2.5 to 2.75 $\mathrm{mmol} / \mathrm{L}$ and $1.5 \mathrm{mmol} / \mathrm{L}$, respectively, in umbilical cord blood at term.

After the abrupt cessation of placental transfer of $\mathrm{Ca}$ at birth, neonatal total serum Ca falls to 2 to $2.25 \mathrm{mmol} / \mathrm{L}$ ), and ionized Ca falls to levels as low as 1.1 to $1.35 \mathrm{mmol} / \mathrm{L}$ at 24 hours after delivery. Serum Ca concentration subsequently rises, reaching levels seen 
in older children and adults (from 2.1 to 2.7 $\mathrm{mmol} / \mathrm{L}$ ) by two weeks of age $[6,7]$.

Hypocalcemia, low levels of calcium in the blood could be related to 22q11. 2 deletion syndrome [27], and other genetically determined disorders: Di George's syndrome, CATCH 22 syndrome, activating mutations of the calcium sensing resceptor (CSR). Also due to genetically determined metabolic syndromes: Kenny-caffey syndrome, long-chain fatty acyl CoA dehydrogenase deficiency, Kearns-sayre syndrome [27]. In addition, hypocalcaemia may be iatrogenic due to neonatal therapy: blood componenets, lipid infusions, bicarbonate therapy, diuretics (loop diuretics), glucocorticosteroids, phosphate therapy, Alkalosis, Phototherapy, aminoglycosides (mainly gentamicin), viral gastroenteritis, phototherapy, high phosphate intake (cow milk) $[3,10,28]$. Newborn hypocalcemia can also occur as a result of excessive maternal calcium intake during pregnancy [29]. Neonatal asphyxia, can lead to elevated levels of serum calcitonin, which inhibits calcium leaching from bones and consequential low calcium levels in blood [10].

The work of Rayannavar et al indicates that hypocalcemia is associated with congenital heart disease in deletion syndrome 22q11.2, however in our case the ECHO of the heart indicated a physiological finding of the heart cavities and valves which excludes the etiology of this syndrome [30].

The newborn in this case is male. In the study of Thomasa TC on 78 newborns, it was established that hypocalcemia is more common in male newborns. (71.8\%) Moderate-to-severe late-onset neonatal hypocalcemia is more common in male infants [31].

Kargar et al. suggest that hypocalcemia may occur due to phototherapy [32]. In our case, the appearance of symptoms of hypocalcemia after transfusion cannot be explained by the additional effect of phototherapy because phototherapy ended in the first week of life and hypocalcemia as part of transfusion occurred at the end of the first month of life [14]. The occurrence of hypocalcemia cannot be explained by a diet based on cow's milk formula because the child is fed an adapted milk formula for artificial feeding of newborns-Aptamil [16].

Cases of hypocalcaemia due to the use of antibiotics, primarily amikacin, have been described. Since we have therapeutically administered amikacin in the case of our newborn, we can consider it an additional factor in the development of hypocalcemia [15].

Transfusion reactions can occur to all the ingredients present in a unit of blood. In addition to ATR on blood components, adverse reactions may also occur to the optimal additive solution (OAS) [33,34]. and other unexpected ingredients [18]. When large volumes of blood components containing citrate are transfused rapidly, increased plasma citrate chelates calcium ions resulting in hypocalcaemia and its symptoms. Hypocalcaemia caused by citrate overload can usually be treated by slowing down the infusion rate. Calcium replacement is indicated in massively transfused patients, particularly those with severe liver disease or if symptoms of hypocalcaemia are severe [34]. OAS is used to preserve the functionality of blood components, during storage, with citrate being its obligatory ingredient. Citrate is necessary to prevent blood clotting, to keep blood components fluid and functional until use. Stored blood is anticoagulated using citrate (3 g/unit of RBC), so pediatric unit of $50 \mathrm{ml}$ contains approximately ten times less citrate $(0.3 \mathrm{~g})$. In our case the newborn of $2 \mathrm{~kg}$ received a total of $0.3 \mathrm{~g}$ which is $0.15 \mathrm{~g} / \mathrm{kg}$. There are reported that during massive transfusion in adults, sodium citrate of $0.317 \mathrm{~g} /$ $\mathrm{kg} / \mathrm{hr}$ was fatal therefore in preterm infants the risk is higher because citrate clearance is reduced due to immature liver $[19,23]$.

According to the guidelines, the transfusion rate in neonatology is of $5 \mathrm{~mL} / \mathrm{kg} /$ $\mathrm{hr}$. The total therapeutic dose is generally 15 $\mathrm{mL} / \mathrm{kg}$ for non-bleeding neonates $[25,35]$. In neonates at risk for developing hypoclycemia (maternal diabetes, prematurus, neonatal asphyxia), the transfusion rate needs to be adjusted [36]. When there are clinically justified reasons for the occurrence of hypocalcemia such as maternal diabetes, growth retardation, preeclampsia, autoimmune diseases and the child undergoes phototherapy, the recommended transfusion rate should be reduced to the lowest possible level $(1 \mathrm{~mL} / \mathrm{kg} / \mathrm{hr})[9$, 31,36].

An acronym CATS: convulsions, arrhythmias, tetany, stridor and spasms is used for complicatioons due to hypocalcemia [37].

Critically ill patients receiving transfusions are often unstable and can therefore present signs and/or symptoms compatible with ATRs during or after transfusion. Thus 
ATRs may be underdiagnosed in these critically ill children, with signs and symptoms being attributed to the patient's underlying disease.

Although transfusion-induced side effects are rare, clinicians should consider neonatal hypocalcemia prevention measures as an effective therapeutic approach. Measures to prevent hypocalcemia include: Proper control of blood sugar during pregnancy may help avoid development of neonatal hypocalcemia. Regular medical screening at periodic intervals with tests and physical examinations are strongly recommended for pregnant women with gestational diabetes, hyperparathyroidism, or any other illnesses [11]. Among blood tests, ionized calcium, phosphate, alkaline phosphatase, magnesium, albumin, and creatinine levels in addition to serum total calcium level should be measured [11].

To evaluate calcium (Ca) status, we recommend measurement of ionized $\mathrm{Ca}$ in whole blood rather than total $\mathrm{Ca}$, because it more accurately reflects the physiologically available $\mathrm{Ca}[6,11]$.This is particularly important in the first week of life when hypocalcemia is most common and accurate assessment is essential.

Awareness of transfusion risks has led to a reduction in the number of transfusions given to newborns with birth weights from $1.0-1.5 \mathrm{~kg}$ from $83 \%$ in 1982 to $36 \%$ in 1993 $[38,39,40]$. The results of the study by Kirpallani et al., as well as the ETTNO Randomized Clinical Trial, did not show a protective benefit of RBC transfusion for cognitive disorders, ie the advantage of the liberal over the restrictive transfusion approach. [40,41].

The studies indicate that transfusion was often applied where it was not necessary $[38,42]$. In order to reduce transfusion adverse reactions in the most vulnerable pediatric subpopulation of VLBW neonates, it is necessary to enable close and continuous collaboration between pediatricians-neonatologists, transfusion medicine specialists and clinical pharmacologists in order to obtain "dedicated” blood components, both with regards to quality and quantity. able to meet the particular needs of the neonate, especially considering the now increased survival of extremely low birth weight (ELBW) babies and to establish appropriate transfusion criteria for these VLBW infants and write modern guides with precise criteria and recommendations [43].
Transfusion in pediatrics and neonatology should be used in accordance with the recommendations for transfusion in pediatrics and neonatology. In the further development of these transfusion indications, it is necessary to report in more detail the adverse reactions to transfusion in neonatals and prematures $[1,35,36,44]$.

\section{CONCLUSION}

Transfusion advere reaction in our case occurred due to sodium citrate overload. The newborn received $50 \mathrm{~mL}$ of $\mathrm{RBC}$ so he received a total $0.3 \mathrm{~g}$ of citrate or $0.15 \mathrm{~g} / \mathrm{kg}$.

The newborn in our case was at higher risk of developing symptoms of hypocalcemia because he was born prematurely, his mother is diabetic and he was on photo therapy and antibiotic therapy.

Improved surveillance of transfusions given to PICU patients and better knowledge of these reactions by health care professionals should enhance the safety of transfusions by early recognition of reactions.

Hemovigilance systems should aim at identifying specifically the number and types of adverse transfusion reactions that occur in the pediatric population because the incidence of the events may differ from the adult population. Successful pediatric haemovigilance is possible with multidisciplinary teams of pediatricians, clinical transfusiologists and clinical pharmacologists.

Future studies should evaluate incidence rate of adverse transfusion reactions in newborns reported by hemovigilance systems compared to observation prospective studies. The autors insist on respecting side effects reporting and introduction of stimulation and the possibility of sanctioning within the audit control.

\section{CONFLICTS OF INTEREST}

All authors declare no conflict of interest.

\section{REFERENCES}

1. Abrams SA. Section Editors: Garcia-Prats JA, Wolfsdorf JI, Deputy Editor: Kim MS. ( Neonatal hypocalcemia. This topic last updated: May 19, 2020. available at: https://www.uptodate.com/ contents/neonatal-hypocalcemia

2. Brookwood Baptist Hypocalcemia. Last full review/revision Apr 2020| Content last modified Apr 
2020. https://www.msdmanuals.com/professional/endocrine-and-metabolic-disorders/electrolytedisorders/hypocalcemia

3. Zhou P, Markowitz M. Hypocalcemia in Infants and Children. Pediatrics in Review May 2009, 30 (5) 190-192; DOI: https://doi.org/10.1542/pir.30$5-190$

4. Cho WI, Yu HW, Chung HR, Shin $\mathrm{CH}$, Yang SW, Choi CW, Kim BI. Clinical and laboratory characteristics of neonatal hypocalcemia. Ann Pediatr Endocrinol Metab. 2015;20(2):86-91. doi:10.6065/ apem.2015.20.2.86

5. Dysart KC. Neonatal Hypocalcemia. Content last modified Mar 2021, https://www.msdmanuals. $\mathrm{com} / \mathrm{professional/pediatrics/metabolic-electro-}$ lyte-and-toxic-disorders-in-neonates/neonatal-hypocalcemia, Downloaded 18.09.2021

6. Kovacs CS. Bone development and mineral homeostasis in the fetus and neonate: roles of the calciotropic and phosphotropic hormones. Physiol Rev 2014; 94:1143.

7. Kovacs CS. Calcium, phosphorus, and bone metabolism in the fetus and newborn. Early Hum Dev 2015; 91:623.

8. Schafer AL, Shoback DM. Hypocalcemia: Diagnosis and Treatment. [Updated 2016 Jan 3]. In: Feingold KR, Anawalt B, Boyce A, et al., editors. Endotext [Internet]. South Dartmouth (MA): MDText. com, Inc.; 2000-. Available from: https://www. ncbi.nlm.nih.gov/books/NBK279022/

9. Levy-Shraga Y, Dallalzadeh K, Stern K, Paret G, Pinhas-Hamiel $O$. The many etiologies of neonatal hypocalcemic seizures. Pediatr Emerg Care. 2015 Mar;31(3):197-201.

10. Long, K., Cartwright, T., Sloan, D., \& Lee, C. (2015). Cystic multiglandular maternal hyperparathyroidism diagnosed by neonatal hypocalcemic seizures. Journal of surgical case reports, 2015(3), rjv031.

11. Vuralli D. Clinical Approach to Hypocalcemia in Newborn Period and Infancy: Who Should Be Treated? Int J Pediatric, 2019; Volume 2019, Article ID 4318075, 7 pages, doi.org/10.1155/2019/4318075.

12. Do HJ, Park JS, SeoJH, Lee ES, Park $\mathrm{CH}$, Woo HO, Youn HS. Neonatal Late-onset Hypocalcemia: Is There Any Relationship with Maternal Hypovitaminosis D? Pediatric Gastroenterology, Hepatology \& Nutrition, 2014;17(1), 47-51. http://doi. org/10.5223/pghn.2014.17.1.47

13. Chacham S, Ravikiran J, Reddy UN, Rao JN, Reddy M, Imeduddin. Symptomatic late onset hypocalcemia in a full term female neonate with vitamin $D$ deficiency due to maternal hypovitaminosis D: A rare case report. Int J Case Rep Images 2015;6(5):276-279. doi:10.5348/ijcri-201544CR-10505, http://www.ijcasereportsandimages. com/archive/2015/005-2015-ijcri/CR-10505-052015-chacham/ijcri-1050505201505-chacham.pdf
14. Alizadeh-Taheri P, Sajjadian N, Eivazzadeh B. Prevalence of phototherapy induced hypocalcemia in term neonate. Iran J Pediatr. 2013;23(6):710-1.

15. Jackson GL, Sendelbach DM, Stehel EK, Baum M, Manning MD, Engle WD. Association of hypocalcemia with a change in gentamicin administration in neonates. Pediatr Nephrol. 2003;18(7):653-6. doi: $10.1007 / \mathrm{s} 00467-003-1161-\mathrm{x}$

16. Venkataraman PS, Tsang RC, Greer FR, Noguchi A, Laskarzewski P, Steichen JJ. Late infantile tetany and secondary hyperparathyroidism in infants fed humanized cow milk formula. Longitudinal followup. Am J Dis Child. 1985;139(7):664-8. Cow Milk

17. Uppal P, Lodha R, Kabra SK. Transfusion of Blood and Components in Critically III Children Indian J Pediatr (2010) 77:1424-1428 DOI 10.1007/s12098010-0194-y

18. Sundararajan S, Blatz AM, Dearborn DG, Varnes AW, Bearer CF. Toxic Metal Contamination of Banked Blood Designated for Neonatal Transfusion. J Clin Toxicol 2015;5: 267. doi:10.4172/21610495.1000267

19. Goel R, Tobian AAR, Shaz BH. Non-infectious transfusion associated adverse events and their mitigation strategies. Blood, 2019;133(17), DOI 10.1182/blood-2018-10-833988

20. Guo K, Wang $X$, Zhang $H$, Wang $M$, Song $S$, Ma S. Transfusion Reactions in Pediatric Patients: An Analysis of 5 Years of Hemovigilance Data From a National Center for Children's Health in China. Front Pediatr. 2021 May 28;9:660297. doi: 10.3389/ fped.2021.660297

21. King KE, Ness PM. Treatment of autoimmune hemolytic anemia. Semin Hematol. 2005;42:131-136.

22. Balint B, Ostojic G, Pavlovic M, Hrvacevic R, Tukic L, Radovic M. Cytapheresis in the treatment of cell-affected blood disorders and abnormalities. Transfus Apher Sci 2006;35:25-31.

23. Gauvin F, Lacroix J, Robillard P, Lapointe H, Hume $H$. Acute transfusion reactions in the pediatric intensive care unit. Transfusion. 2006;46(11):1899908. doi: $10.1111 /$ j.1537-2995.2006.00995.x. PMID: 17076844 .

24. Roseff SD, Luban NLC, Manno CS. Guideline for assessing appropriateness of pediatric transfusion. Transfusion practice. 2002;42(11):1398-413. doi: 10.1046/j.1537-2995.2002.00208.x. PMID: 12421212 .

25. Transfusion Handbook: 10.2 Neonatal transfusion, Joint United Kingdom (UK) Blood Transfusion and Tissue Transplantation Services, Professional Advisory Committee: 2021. Editor: Dr Derek Norfolk, Caroline Smith. United Kingdom Blood Services 5th edition,TSO, Last updated 01/04/2020. Available on: http://www.transfusionguidelines.org/ transfusion-handbook/10-effective-transfusion-inpaediatric-practice/10-2-neonataltransfusion 
26. Ali SKM, Mohammed N, Qureshi N, Gupta S. Oxygen therapy in preterm infants: recommendations for practice, Paediatrics and Child Health, 2021;31(1):1-6. doi.org/10.1016/j. paed.2020.10.001

27. Fujii S, Nakanishi T. Clinical manifestations and frequency of hypocalcemia in 22q11. 2 deletion syndrome. Pediatrics International, 2015;57(6), 1086-1089.

28. Rigo J, Curtis MD.Disorders of Calcium, Phosphorus and Magnesium Metabolism in Richard J Martin, Avory A Fanaroff, Michele C Walsh(eds). Neonatal Perinatal Medicine- Diseases of th the fetus and infant. 8 edition;Elsevier, Pihladelphia, 2006: p1508- 14.

29. Borkenhagen JF, Connor EL, Stafstrom CE. Neonatal hypocalcemic seizures due to excessive maternal calcium ingestion. Pediatr Neurol. 2013 Jun;48(6):469-71. doi: 10.1016/j.pediatrneurol.2013.02.010. PMID: 23668874.

30. Rayannavar A, Levitt Katz LE, Crowley TB, Lessig M, Grand K, Goldmuntz E, Zackai EH, MCDonald-McGinn DM. Association of hypocalcemia with congenital heart disease in 22q11.2 deletion syndrome. Am J Med Genet A. 2018;176(10):20992103. doi:10.1002/ajmg.a.40495.

31. Thomas TC, Smith JM, White PC, Adhikari S. Transient neonatal hypocalcemia: presentation and outcomes. Pediatrics 2012; 129:e1461-e1467.

32. Kargar M, Jamshidi Z, Beheshtipour N, Pishva $\mathrm{N}$, Jamali M. Effect of head covering on phototherapy-induced hypocalcaemia in icterus newborns; a randomized controlled trial. Int J Community Based Nurs Midwifery. 2014;2(2):121-126

33. Sahu S, H, Verma A. Adverse events related to blood transfusion. Indian J Anaesth 2014;58:54351. https://www.ncbi.nlm.nih.gov/pmc/articles/ PMC4260299/pdf/IJA-58-543.pdf

34. Dzik WH, Kirkley SA. Citrate toxicity during massive blood transfusion. Transfus Med Rev. 1988;2:76-94.

35. Hanson SJ, Owen EB, McDonald MJ, Woods KJ, Montgomery VL. Standardized Implementation of Evidence-based Guidelines to Decrease Blood Transfusions in Pediatric Intensive Care Units. Pediatr Qual Saf. 2019 Apr 9;4(3):e165. doi: 10.1097/ pq9.0000000000000165

36. New HV, SJ Stanworth, R Gottstein, C Cantwell, J Berryman, EA Chalmers, PHB Bolton-Maggs on behalf of the BSH Guidelines Transfusion Task Force British Society for Haematology Guidelines on transfusion for fetuses, neonates and older children (Br J Haematol. 2016;175:784-828) Addendum August 2020.

37. Shulman R, O'Gorman CS, Sochett EB. Case 1: Neonate with seizures and hypocalcemia. Pediatr Child Health. 2008;13:197-200.
38. Widness JA, Madan A, Grindeanu LA, Zimmerman $M B$, Wong DK, Stevenson DK. Reduction in red blood cell transfusions among preterm infants: results of a randomized trial with an in-line blood gas and chemistry monitor. Pediatrics. 2005;115(5):1299. 1306. doi:10.1542/peds.2004-1680

39. O'Riordan JM, Fitzgerald J, Smith OP, Bonnar J, Gorman WA. Neonatal and Fetal Transfusion, In: Transfusion of Blood Components to Infants under Four Months: Review and Guidelines, IMJ, 2007;100(6):1-5].

40. Kirpalani H, Bell EF, Hintz SR, Tan S, Schmidt B, Chaudhary AS, Johnson KJ, Crawford MM, Newman JE, Vohr BR, Carlo WA, D'Angio CT, Kennedy KA, Ohls RK, Poindexter BB, Schibler K, Whyte RK, Widness JA, Zupancic JAF, Wyckoff MH, Truog WE, Walsh MC, Chock VY, Laptook AR, Sokol GM, Yoder BA, Patel RM, Cotton CM, Carmen MF, Devaskar U, Chawla S, Seabrook R, Higgins RD, Das A, for the Eunice Kennedy Shriver NICHD Neonatal Research Network. Higher or lower hemoglobin transfusion treshholds for preterm infants. N Engl J Med, 2020;383(27):2639-2651. DOI: 10.1056/ NEJMoa2020248, https://www.nejm.org/doi/ pdf/10.1056/NEJMoa2020248?articleTools=true

41. Franz AR, Engel C, Bassler D, Rüdiger M, Thome UH, Maier RF, Krägeloh-Mann I, Kron M, Essers J, Bührer C, Rellemsmann G, Rossi R, Bittrich HJ, Roll C, Höhn T, Ehrhardt H, Avenarius S. Körner HT, Stein A, Buxmann H, Vochem M, Poets CF; for the ETTNO Investigators. Effects of Liberal vs Restrictive Transfusion Thresholds on Survival and Neurocognitive Outcomes in Extremely Low-BirthWeight Infants The ETTNO Randomized Clinical Trial. JAMA 2020;324(6):560-570. doi:10.1001/ jama.2020.10690

42. Patel RM, Hendrickson JE, Nellis ME, Birch R, Goel R, Karam O, Karafin MS, Hanson SJ, Sachais BS, Hauser RG, Luban NLC, Gottschall $J$, Josephson CD, Sola-Visner M; National Heart, Lung, and Blood Institute Recipient Epidemiology and Donor Evaluation Study-IV-Pediatric (REDS-IVP). Variation in Neonatal Transfusion Practice. J Pediatr. 2021 Aug;235:92-99.e4. doi: 10.1016/j. jpeds.2021.04.002.. PMID: 33836184; PMCID: PMC8316298.

43. Girelli G, Antoncecchi S, Casadei AM, et al. Recommendations for transfusion therapy in neonatology. Blood Transfus. 2015;13(3):484-497. doi:10.2450/2015.0113-15

44. Zantek ND, Parker RI, van de Watering LM, Josephson CD, Bateman ST, Valentine SL, Delaney M; Pediatric Critical Care Transfusion and Anemia Expertise Initiative (TAXI); Pediatric Critical Care Blood Research Network (BloodNet), and the Pediatric Acute Lung Injury and Sepsis Investigators (PALISI) Network. Recommendations on Selection and Processing of RBC Components for Pediatric Patients From the Pediatric Critical Care Transfusion and Anemia Expertise Initiative. Pediatr Crit Care Med. 2018 Sep;19(9S Suppl 1):S163-S169. doi: 10.1097/PCC.0000000000001625. 


\section{Hipokalcemija novorođenčeta usled transfuzije eritrocita: prikaz slučaja}

Biljana S. Otašević, Bojana O. Petrović, Emina S. Čolak, Tatjana V. Nikolić, Aleksandar O. Stefanović, Ljubinka I. Nikolić

Univerzitetski Klinički centar Srbije, Beograd, Srbija

\section{KRATAK SADRŽAJ}

Uvod: Kod prevremeno rođene dece može biti rana i kasna. Uzroci kasne hipokalcemije: deficijencija vitamina $D$ majke, metabolički sindromi, kongenitalne abnormalnosti, jatrogeni (transfuzija, terapija bikarbonatima, fototerapija, antibiotici).

Prikaz slučaja: Autori opisuju pojavu hipokalcemije kod prevremeno ređenog drugog blizanca (32/33 nedelje gestacije) nakon transfuzije eritrocita. Majka je u trudnoći imala dijabetes, hipertenziju, edeme, hipotiroidizam i preeklampsiju. Zbog detektovane pijelektazije novorođenčetu je ordiniran cefaleksin. Krajem prvog meseca živora novorođenče pokazuje znake anemije zbog čega je transfundovano sa $50 \mathrm{ml}$ leukoredukovanih eritrocita krvne grupe $0+$. Neposredno nakon završetka transfuzije stanje novorođenčeta se pogoršava. Javlja se cijanoza ukočenost, trizmus I bradikardija u trajanju od nekoliko sekundi. DAT je negativan, bilirubin u referentnom opsegu. Nakon transfuzije, vrednosti laboratorijskih, ultrazvučnih, neuroloških nalaza, EEG i EKG su u fiziološkim granicama. Zaključeno je da je neželjena reakcija najverovatnije prouzrokovana transfuzijom.

Zaključak: Kod prevremeno rođene dece hipokalcemija se može javiti u toku transfuzije zbog preopterećenja citratom. Deca majki dijabetičara, deca na antibiotskoj i foto terapiji su u većem riziku za razvoj hipokalcemije. Potrebne su buduće studije da evaluiraju incidence neželjenih transfuzijskih reakcija kod novorođenčadi.

Ključne reči: hipokalcemija, novorođenče, citrat, transfuzijske neželjene reakcije 